\title{
Könyvszemle
}

SIPOS JÚLIA GONDOZÁSÁBAN

\section{EGYMÁS SZEMÉBE NÉZVE - AZ ELMÚLT FÉL ÉVSZÁZAD ROMAPOLITIKAI TÖREKVÉSEI}

Az MTA Társadalomtudományi Központ Szociológiai Intézet kiadásában, Kóczé Angéla, Neményi Mária és Szalai Júlia igényes szerkesztésében jelent meg ez a kutatási beszámoló. A kötet a Roma politika intézményesülése címü OTKA-kutatás (105089) alapján készült. A megjelenés azonban nem csupán rutinszerü lezárása egy kutatásnak, hanem igazi hiánypótló munka, és nagyon izgalmas olvasmány.

Már a cím is előre jelzi a kutatás és a kötet legfontosabb célját. Magyarország legnagyobb etnikai kisebbsége, a magyar cigányság történetének és súlyos konfliktusokkal terhelt politikai integrációjának egy nagyon fontos aspektusát kívánták feltárni és bemutatni a kutatók, nevezetesen, hogy az emancipáció elmúlt évtizedeiben hogyan formálódott a roma politikai elit. A látlelet fontos hozzájárulás, hogy a magyar politika szereplöi és maga a többségi társadalom is képes legyen szembenézni a roma kisebbség politikai elfogadásának történetével, és azzal a jórészt sikertelen küzdelemmel, amely a kisebbségi mozgalom vezetőit jellemezte.

Az első fejezetben Kóczé Angéla mutatja be nagyon színvonalasan és alaposan a kötet alapjául szolgáló projektet, a roma politizálás történetét a kezdetektől napjainkig. A bevezetésben Kóczé Angéla a kutatás fontos nóvumára hívja fel a figyelmet. A romák integrációját a gazdag szakirodalom egyszerre vizsgálja két paradigmában, az újraelosztás és az elismerés perspektívájában. Kevés szó esik azonban arról, hogy a roma közösség és a roma politikusok perspektívájából ez a dilemma hogyan tematizálódott. Nagyon fontos megállapítása a szerzőnek, hogy a jóindulatú fejlesztési programok a romákkal szembeni igazságtalanságok orvoslására kizárólag ,affirmative” (megerősítő) beavatkozást tudtak eszközölni. Az említett programok azonban nem kapcsolódtak össze a társadalmi mobilitást biztosító alrendszerekkel, mint például az oktatás, a foglalkoztatáspolitika, a szociálpolitika és a közösségi közlekedés. Az ilyen beavatkozások a társadalomban létező valós feszültségeket és konfliktusokat a roma és a nem roma szegények közötti megosztottságra terelik át. A kutatás nagy kihívása, hogy ezek a fontos 
elméleti keretek hogyan köszönnek vissza a romapolitikában, és a roma politikai szereplők nézeteiben és cselekedeteiben.

A Neményi Mária és Szalai Júlia által jegyzett Elbeszélt évtizedek: A roma politika közelmúltbeli története a roma politikusok szemével címü fejezet a politikacsináló roma elit életútját mutatja be, és hatását a roma politika alakulására. A téma különösen érzékeny, ha figyelembe vesszük az elmúlt évtizedek sokszor izzásig feszült konfliktusait a többségi és a kisebbségi társadalom között, ami még élesebben csapódott le a közélet és a politika szférájában. Éppen ezért is különösen értékelendő a szerzők megközelítésének árnyalt és kiegyensúlyozott tónusa, analitikus szemlélete. A szerzők kutatásuk során ötvenöt interjút készítettek a roma politikai elit szereplöivel (harmincöt közéleti szereplővel és húsz családtaggal). Az interjúk három téma köré szerveződtek: a családi gyökereket, az identitás alakulását, valamint a politikai pályát járják körül.

Az életútinterjúk közös jellemzője, hogy a szereplők hatalmas életpályát futottak be. Szinte minden roma politikusra jellemző, hogy karrierjük egy többlépcsős mobilitáspályát ír le. Az interjúalanyok mindegyike mögött hatalmas emberi eröfeszítés és teljesítmény áll, legtöbben nagy szegénységből jutottak fel pályájuk csúcsára, hihetetlen munka árán.

Kulcsmozzanat az életutakban a szülők támogatása, a sokszor elfojtott szülői vágyak motiváló ereje, a családi minták sokszínüsége. Szinte minden karrierben megjelenik az iskola szerepének felismerése akár a szülők, akár az érintettek gondolkodásában, ami a továbbtanulás, a magasabb iskolázottság, az érettségi fontosságának felismerésében mutatkozik meg. Nagy kihívást jelentett a munka mellett a tanulmányok esti vagy levelezö tagozaton történő teljesítése.

Ugyanakkor ezek a hatalmas életútívek sokszor deficittel is jártak. A szegénységből az elitbe tartó társadalmi mobilitás strukturális folyamata több esetben megkerülte a hagyományos polgári hivatásokat, elmaradt a polgári szocializáció, és a politika mint szakma elmélyült tanulása is hiányzott. Honnan jött akkor mégis az a tudás, készség és érzékenység, ami a roma politikai elitet a közösségi szerepvállalás kihívásaira és nehézségeire felvértezte? Nagyon jellemző ezekben az életutakban a mikroközösségek és a mindennapi roma kultúra szocializációs hatásának szerepe. A későbbi roma elit tagjainak jelentős része roma közösségekbe került, klubokat és táborokat szervezett. A közösségi lét segített a roma kultúra felfedezésében, és ezek a felfedezések aztán mind kapaszkodók lesznek a társadalmi felemelkedés útján. Egyfelöl ezekből az élményekből és tapasztalatokból táplálkozik annak felismerése, hogy mennyire fontos feladat a roma közösség politikai képviseletének és elismerésének kiharcolása, ami sokszor azzal járt, hogy a megkérdezett roma vezetők be is záródnak a saját roma közösségükbe. Másrészt a cigány identitás sokszor negatív tapasztalatokból és a diszkrimináció élményéből táplálkozik, ami felerősíti az etnikai-politikai 
szocializáció mozgalmi, érzelmi alapú gyökereit, amelyből hiányzik a polgári szocializáció mozzanata.

A rendszerváltás után közvetlenül a romák képviselete elsősorban a szociális leszakadás elleni harcra és a közpolitikára való befolyás erősítésére fókuszált, és az országos politika színterei mellett az oktatáspolitika és az önkormányzatok területén vívta a maga harcát. Csak jóval később követi ezt a roma politikai elit körében az etnikai identitás fontosságának felismerése, az identitás formálódásának útkeresése, a különbözőség, kirekesztettség és diszkrimináció élményéből fakadó polgárjogi harcosság, valamint a közösségi élmény és a saját kultúra fontosságának felismerése, és ennek képviselete.

A roma politikai elit életútjának és mai politikai ambícióinak elemzése fontos és aktuális kérdéseket vet fel. Vajon napjainkra mit jelent a politikai elitség a roma elit esetében, miként tudja képviselni a politikai közösséget, mit tudnak nyújtani a romáknak, és egyáltalán fel tudják-e kelteni az érdeklődést maguk iránt, kapnak e társadalmi támogatást, és tudnak-e mintát adni? Vagy a történetük csupán egy exkluzív mozgalmi történet?

A szerzőpáros egyik legfontosabb konklúziója az, hogy a roma politikai elit története arra is rámutat, hogy a folyamat egyben egy útelágazáshoz is elért. Az egyik út a hangsúlyt a közéleti-politikai szerepvállalásra, mozgalmi és polgárjogi harcra és a civil aktivizmusra teszi. A másik út viszont a közpolitikát és szakpolitikákat vette célkeresztbe, és az ebbe a körbe tartozó roma politikusok ebben látták és látják a roma kisebbség politikai céljainak megvalósítását. Az eltérö utakból viszont ideológiai metszéspontok is fakadnak, melyek az asszimiláció és elkülönülés dilemmáját vetik fel.

A kötet zárófejezetében Bogdán Mária azt vizsgálja, hogy az információs társadalom, az internet és a szociális média megjelenése hogyan tükröződik vissza a roma politikai mozgalom müködésében, és milyen új lehetőségeket kínál fel a roma politika számára. Az elemzés inkább látlelet és bemutatás, hogy mi történt a romák önreprezentációja, közösségszervezése, identitásépítése és politikai törekvései tekintetében a virtuális térben. A szerző nagyon sok példát mutat be, többek között sikeres akciókat (Népszámlálás 2011, Roma büszkeség Napja) a pozitív identitásteremtésre, a részvételi demokráciára, a romapolitikai érdekek reprezentációjára, de nem tủnik úgy, hogy ezek folyamatában, napi szinten képesek az aktivitást fenntartani.

A három fejezetet hat kerekasztal-beszélgetés szövege egészíti ki, váltakozó szereplőkkel, nagyon izgalmas vitákat felidézve. Olyan témákat vitatnak meg a résztvevők, mint például, hogy a tudományos megismerés befolyásolta-e a romapolitikát Magyarországon, és hatással volt-e egyáltalán a politika döntéseire, vagy hogy a színtudatos, illetve színvak politika milyen szerepet játszott az oktatás, a foglalkoztatás és a szociális szféra területén a közpolitikai döntésekre. Ugyancsak izgalmasak azok a viták, amelyek a roma politika belső konfliktusai- 
ról, illetve nemzetközi kontextusáról zajlottak. A kötetet a romapolitika különféle fontos dokumentumaiból közölt válogatás zárja be. Sajnálatosan mind a kerekasztal-beszélgetések, mind a mellékelt dokumentumok szövegei a kötetben elemzés nélkül maradnak.

(Kóczé Angéla - Neményi Mária - Szalai Júlia szerkesztők: Egymás szemébe nézve. Az elmúlt fél évszázad romapolitikai törekvései. Szociológiai Tanulmányok 2017/1. Budapest: MTA TK Szociológiai Intézet, 2017, http://mek.oszk. hu/17500/17552/17552.pdf)

Örkény Antal

szociológus, egyetemi tanár Eötvös Loránd Tudományegyetem Társadalomtudományi Kar 